\title{
Divergent responses to peptidoglycans derived from different $E$. coli serotypes influence inflammatory outcome in trout, Oncorhynchus mykiss, macrophages
}

\author{
Sebastian Boltaña ${ }^{1}$, Felipe Reyes-Lopez ${ }^{2}$, Davinia Morera' ${ }^{1}$ Frederick Goetz ${ }^{3}$, Simon A MacKenzie ${ }^{1 *}$
}

\begin{abstract}
Background: Pathogen-associated molecular patterns (PAMPs) are structural components of pathogens such as lipopolysaccharide (LPS) and peptidoglycan (PGN) from bacterial cell walls. PAMP-recognition by the host results in an induction of defence-related genes and often the generation of an inflammatory response. We evaluated both the transcriptomic and inflammatory response in trout (O. mykiss) macrophages in primary cell culture stimulated with DAP-PGN (DAP; meso-diaminopimelic acid, PGN; peptidoglycan) from two strains of Escherichia coli (PGN-K12 and PGN-O111:B4) over time.

Results: Transcript profiling was assessed using function-targeted cDNA microarray hybridisation $(n=36)$ and results show differential responses to both PGNs that are both time and treatment dependent. Wild type E. coli (K12) generated an increase in transcript number/diversity over time whereas PGN-O111:B4 stimulation resulted in a more specific and intense response. In line with this, Gene Ontology analysis (GO) highlights a specific transcriptomic remodelling for PGN-O111:B4 whereas results obtained for PGN-K12 show a high similarity to a generalised inflammatory priming response where multiple functional classes are related to ribosome biogenesis or cellular metabolism. Prostaglandin release was induced by both PGNs and macrophages were significantly more sensitive to PGN-O111:B4 as suggested from microarray data.

Conclusion: Responses at the level of the transcriptome and the inflammatory outcome (prostaglandin synthesis) highlight the different sensitivity of the macrophage to slight differences (serotype) in peptidoglycan structure. Such divergent responses are likely to involve differential receptor sensitivity to ligands or indeed different receptor types. Such changes in biological response will likely reflect upon pathogenicity of certain serotypes and the development of disease.
\end{abstract}

\section{Background}

Detection of pathogens by host organisms requires direct contact between host PRRs (pattern recognition receptors) and pathogen-associated molecular patterns (PAMPs) where PAMP-PRR interactions subsequently dictate the development of the host immune response $[1,2]$. PAMPs such as the lipopolysaccharides (LPS) and peptidoglycans (PGN), both bacterial cell wall components, have been directly implicated in the induction of

\footnotetext{
* Correspondence: Simon.MacKenzie@uab.es

'Institute of Biotechnology and Biomedicine, Universitat Autónoma de Barcelona, 08193 Barcelona, Spain

Full list of author information is available at the end of the article
}

the host immune response across the vertebrata [3-9]. Peptidoglycan and related fragments are recognised by the host and induce diverse biological effects, including inflammation, leukocytosis, or enhanced immune responses [10-13]. Like LPS, peptidoglycan, including its minimal immunomodulatory subunit, muramyl dipeptide, can bind to the CD14 receptor of target cells in mammals [14-16] although peptidoglycan does not bind to LBP or BPI $[17,18]$. PGN's do not activate TLR4mediated signal transduction but do activate both the TLR2 and NOD pathways [19-24].

In Drosophila, PGN recognition is achieved by the Toll or Immune deficiency (Imd) pathways, at least in 
part, through peptidoglycan recognition proteins (PGRPs) [25,26]. Both pathways share common features with mammalian Toll-like receptor (TLR) and tumour necrosis factor $-\alpha$ (TNF- $\alpha$ ) receptor signalling cascades that regulate NF- $\kappa \mathrm{B}$ activation [27-29]. In vivo studies in the zebrafish have shown that the PGRP response is essential for successful responses to bacterial infection [30]. Recently, PGN in trout macrophages has been shown to be the major stimulatory component in crude LPS preparations characterised by an increase in cytokine mRNAs, IL-1 $\beta$ and IL-6, and release of inflammatory products as prostaglandin $\mathrm{E}_{2}\left(\mathrm{PGE}_{2}\right)$ [9]. However, studies addressing different responses to serotypespecific PGNs are scarce throughout the vertebrata including mammals.

PGN may account for approximately one-half of the cell wall mass in gram-positive bacteria whereas in gram-negative bacteria only a relatively thin PGN layer in the periplasmic space is present [31,32]. Gramnegative peptidoglycan contains meso-diaminopimelic acid (DAP) as the major peptide group that is directly cross-linked whereas most gram-positive bacteria have L-lysine as the third amino acid (Lys-type). These Lystype peptides are cross-linked through an inter-peptide bridge that varies in length and amino acid composition in different bacteria [32-34].

As the structure and composition of the microbial motif has an important role in host sensing and minor modifications in structure can influence the immune response [35-38] we explored the response of differentiated trout macrophages in cell culture to different PGNs from E. coli of different strains (K12 and O111: B4). Our results show that trout macrophages differentially respond to different PGNs at the level of the transcriptome by either differentially activating RNA transcripts related to prostaglandin synthesis resulting in the liberation of prostaglandin's (PGN-O111:B4) or by generating a non-defined inflammatory response, (PGN-K12).

\section{Methods}

\section{Animals and Materials}

Healthy adult specimens (160 g mean weight) of rainbow trout (O. mykiss) were purchased from a commercial hatchery (Piscifactoria Andrés, St Privat, Girona) and held in recirculating freshwater stock tanks (300 L) in the aquarium facilities at the Universitat Autònoma de Barcelona. Fish were kept at $15^{\circ} \mathrm{C}$ with a $12 \mathrm{~h}$ light/ $12 \mathrm{~h}$ dark photoperiod cycle, and were fed with a maintenance ratio of about $0.5 \%$ body weight per day. Water quality indicators (dissolved oxygen, ammonia, nitrite, $\mathrm{pH}$ ) were analysed periodically.

DMEM and FBS were purchased from PAA Laboratories (Spain). Poly-D-lysine was purchased from Sigma
(Tres Cantos, Madrid). Primocin, and PGN preparations (PGN E. coli K12, O111:B4) were purchased from Invivogen (Nucliber, Spain). Cell strainers and plasticware were purchased from BD Biosciences (Madrid, Spain). Gel Green was purchased from Biotium (Labnet, Spain). Prostaglandin $E_{2}$ and $D_{2}$ enzyme immunoassay (EIA) kit was from Cayman (Scharlab, Spain).

\section{Cell culture and stimulation}

The experimental protocols used for head kidney isolation have been reviewed and approved by the Ethics and Animal Welfare Committee of the Universitat Autonoma de Barcelona, Spain. After anaesthetising the fish in 3 -aminobenzoic acid ethyl ester $(0.1 \mathrm{~g} / \mathrm{L})$, animals were sacrificed and the head kidney was dissected out. Trout macrophages were isolated as previously described [39]. Before stimulation, differentiated macrophages were incubated in serum free medium for $3 \mathrm{~h}$. For stimulation, the medium of each well was removed and fresh medium containing the indicated concentrations of PGN were added and the cultures were incubated for the indicated times.

\section{RNA extraction and complementary DNA (cDNA) synthesis}

Total RNA was extracted from cell cultures using $1 \mathrm{~mL}$ of TriReagent (Molecular Research Center) per well cell culture, following the manufacturer's instructions. Quantification was carried out with a Nanodrop1000 (Thermo Scientific) and the quality of the RNA was checked with a Bioanalyzer (Agilent technologies). All RNA samples had a RIN value $>7$. Total RNA $(2 \mu \mathrm{g})$ was used to synthesise cDNA with SuperScript III Transcriptase (Invitrogen) and oligo-dT primer (Promega).

\section{Measurement of $\mathrm{PGE}_{2}$ and $\mathrm{PGD}_{2}$ levels}

Supernatants from stimulated cell cultures (triplicates) from 3 different fish were recovered, centrifuged and stored at $-80^{\circ} \mathrm{C}$ until use. Measurement of $\mathrm{PGE}_{2}$ and $\mathrm{PGD}_{2}$ levels was completed with a monoclonal EIA according to the manufacturer's instructions. The prostaglandin kit detection limit was $8 \mathrm{pg} / \mathrm{mL}$. Prior to prostaglandin determination supernatants were diluted five times in EIA assay buffer. The same macrophage cells were used to obtain total RNA for the determination of COX-2 and Prostaglandin D synthase gene expression as well as the supernatants for $\mathrm{PGE}_{2}-\mathrm{PGD}_{2}$ determination.

\section{Microarray analysis}

The design of the microarray is described in detail elsewhere $[40,41]$ and a full description of the platform and data presented in this manuscript are accessible through the public GEO depositories (accession number 
GPL6154 and GSE22330). The genes were selected by functional classes; random clones from common and subtracted cDNA libraries 1800 genes printed in six replicates each were compared with the known vertebrate proteins using BlastX; overall, the platform was enriched in a number of functional classes, such as immune response (236 genes), signal transduction (245 genes), receptor activity (126 genes), apoptosis (120 genes), cell cycle (70 genes), protein catabolism (90 genes), folding (70 genes), response to oxidative stress (39 genes), stress and defence response (145 and 105 genes, respectively), and chaperone activity (41 genes). Total RNA was extracted from cell cultures using $1 \mathrm{~mL}$ of TriReagent (Molecular Research Centre) per well, following the manufacturer's instructions, the quantity and integrity was analysed by Experion RNA StdSens Analysis Kit (BioRad). Microarray analyses were conducted in pooled samples (see experimental design of microarray assay). A dye-swap design of hybridisation was applied. In analyses of infected immune cells, the non-infected cells were used as a control. Each sample was analysed with two slides. Scanning was performed with Alphascan (High Performance Dual-Laser Scanner for Microarray Slides from Alpha Innotech and images were processed with VisionLite (ThermoSpectronic). The measurements in spots were filtered by criteria $\mathrm{I} / \mathrm{B} \geq 3$ and $(\mathrm{I}-\mathrm{B}) /(\mathrm{SI}+$ $\mathrm{SB}) \geq 0.6$, where $\mathrm{I}$ and $\mathrm{B}$ are the mean signal and background intensities and SI, SB are the standard deviations. After subtraction of mean background, locally weighted non-linear regression (Lowess) normalisation [42] was performed separately for each slide. To assess differential expression of genes, the normalised log intensity ratios were analysed with Student's t-test $(\mathrm{p}<0.01)$. The Bayesian modification to the false discovery rate (FDR) was used to correct for multiple comparison tests, estimating the q-value for the set of differentially expressed genes [43]. The functional categories of Gene Ontology [44] were compared with regulated genes $(p<0.01)$ by the sums of ranks (Student t-test $p<0.05$ ). The statistical significance of over-represented functional categories, showing the differential expression in the experiment grouped by functional classes compared with all genes an GO categories from the chip, was assessed using the Chi square test with Yates correction $(p<0.05)$.

\section{Real-Time quantitative PCR and validation}

In order to verify microarray results, real-time PCR (qRT-PCR) was carried out. Two micrograms of the individuals RNA was used to synthesise cDNA with SuperScript III RNase Transcriptase (Invitrogen) and oligo-dT primer (Promega). As a house-keeping gene, $18 \mathrm{~S}$ was amplified from the same cDNA samples. For different gene expression analysis specific primers were used (Additional file 1). Real-time PCR reactions were carried out in a $25 \mu \mathrm{L}$ reaction with SYBR Green I (Stratagene) using a 1:25 dilution of the cDNA and $250 \mathrm{nM}$ of primers. Quantitative qRT-PCR was performed using a Mx 3000P System (Stratagene) and quantification was done according to the Pfaffl method corrected for efficiency for each primer set [45]. Values for each sample were expressed as "fold differences", calculated relative to controls group and normalised for each gene against those obtained for the house keeping gene 18S.

\section{Experimental design \\ Microarray analysis}

macrophage cell cultures isolated from 84 animals were stimulated with PGNs from E.coli O111:B4 and K12 strains and compared to parallel control cultures (without stimulation). Cell cultures were individually stimulated with both peptidoglycans for 1, 6 and $12 \mathrm{~h}$ (12 by PGN and time, $\mathrm{n}=72$ ), and 12 control cultures (total; $\mathrm{n}=84)$. Individuals RNAs were grouped into three pools from 4 cell cultures for each time point $(1,6$, and $12 \mathrm{~h}$ ). The transcriptomic response was analysed by microarray assay, and divided in three experimental time points named early $(1 \mathrm{~h})$, median $(6 \mathrm{~h})$ and late stage $(12 \mathrm{~h})$. The analysis was carried out with common genes expressed within three replicate pools over the control (GDE one way ANOVA p > 0.01). The qRTPCR validation assay was conducted with total RNA from late stage cell cultures.

\section{Time Course}

macrophage cell cultures isolated from 9 animals were stimulated with PGN O111:B4 and K12 during 0, $30 \mathrm{~min}, 1,3,6$, and $12 \mathrm{~h}(10 \mu \mathrm{g} / \mathrm{mL})$. The mRNA abundance of COX-2 (or prostaglandin endoperoxide synthase 2) and PTGDS was measured by qRT-PCR, prostaglandin release $\left(\mathrm{PGE}_{2}-\mathrm{PGD}_{2}\right)$ were measured using a prostaglandin EIA assay (Cayman). Three individual replicates were made for each peptidoglycan stimulation. The control group was non-stimulated cell cultures $(\mathrm{n}=3)$.

\section{Dose-Response}

macrophage cell cultures isolated from 9 animals were stimulated with PGN from the E. coli strains 0111:B4 and K12. The treatment was conducted overnight (12 h) with different concentrations, $0,0.1$ and $10 \mu \mathrm{g} / \mathrm{mL}$, of PGNs. Expression of COX-2 and PTGDS mRNAs was measured by qRT-PCR, prostaglandin release ( $\mathrm{PGE}_{2}$ $\mathrm{PGD}_{2}$ ) were measured using a prostaglandin EIA assay (Cayman). Three individual replicates were made for each peptidoglycan stimulation. The control group was non-stimulated cell cultures $(\mathrm{n}=3)$.

\section{Statistical analysis}

All statistical analysis was conducted with the software SPSS Statistic 17.0. The relationship between intensity 
of expression and time was examined and tested for significant differences between the PGNs with covariance analysis (ANCOVA) using the transcriptomic magnitude as co-variable, followed by one-way ANOVA analysis for up- or down regulated transcripts. The Student t-test was made to explore the difference between the expression registered in the microarray assay and the qRTPCR (Additional file 2). Two-way ANOVAs were made to compare the differences between COX-2 and PTGDS expression and prostaglandin release in the time-course and dose-response assay.

\section{Results}

Global comparisons of the transcriptomic response to PGN (microarray analysis at 1, 6, and 12 hours)

Microarray analyses were evaluated using a salmonidspecific targeted cDNA microarray containing 1800 cDNAs enriched with immune system related genes (SFA 2.0). Gene expression profiles obtained highlighted a marked contrast in the macrophage response to PGN purified from E. coli (PGN-O111:B4 and K12). Samples were taken over time early $(1 \mathrm{~h})$, median $(6 \mathrm{~h})$ and late stage $(12 \mathrm{~h})$ and separate one-way ANOVAs $(p>0.01)$ were conducted to identify differentially expressed transcripts over the control (GDE). Transcripts expressed within all three biological replicates were used to analyse changes for both treatment (PGN) and time stage (Additional files 3, 4, 5, 6, 7, 8). The kinetics of the response obtained from peptidoglycans derived from K12 or O111:B4 were significantly different in both transcript number (total number of differentially expressed transcript over the control, one-way ANOVA $p<0.01$ ) and intensity (fold change $\mathrm{FC}>2$ ) (Figure 1). In total 819 transcripts were differentially expressed (GDE) in both treatments over the control (all cDNAs expressed on the array), with 270, 221 and 328 in the early stage, median and late stages respectively (Figure 1, and Additional file 3, 4, 5, 6, 7, 8, 9). Stimulation with PGN-O111:B4 revealed a significant peak in intensity at the median stage (130 transcripts one-way ANOVA $p<$ 0.01 and $F C>2$; 92) and a strong and intense response was maintained throughout $(\mathrm{FC}>2 ; 51,92$ and 72 at 1 , 6 and $12 \mathrm{~h}$ respectively). In contrast PGN-K12 induced a significant diversity of transcripts (magnitude) over time, note a decrease at $6 \mathrm{~h}$, where the response intensity although high at $1 \mathrm{~h}$ ( $\mathrm{FC}>2 ; 134$ transcripts) significantly decreased through time where late stage transcripts with $\mathrm{FC}>2$ represent only $17 \%$ of the early stage total (Figure 1, Additional file 9). Regression analysis (up regulated genes ANCOVA, $\mathrm{F}_{5}, 68=1.178 p>$ 0.05 , followed by two-way ANOVA, $\mathrm{F}_{2,68}=27.124: p<$ 0.05 ; down regulated genes ANCOVA, $\mathrm{F}_{5,68}=2.303$ : $p>0.05$, followed by two-way ANOVA, $\mathrm{F}_{2,68}=37.124$ : $p<0.05$ ) (Additional file 10, and 11) highlights that a stronger induction of gene expression and likely more directed response is obtained with PGN-O111:B4 challenge.

Qualitative comparisons of the transcriptomic response to PGN: Differentially expressed transcripts in early, median, and late stages of activation

\section{Early stage}

A higher number of induced transcripts were observed with PGN-K12 treatment in respect to PGN-B4 highlighting a common down-regulation of inflammatory processes (Table 1 and 2). Major differences could also be identified in ligand recognition where macrophages stimulated with PGN-K12 up-regulated BPI binding protein (BPI). In fish, BPI has been suggested to be involved in LPS binding and recognition [46] whereas PGN-B4 stimulation led to up-regulation of antigen-processing including MHC I, and MARCO. The alternative spliced

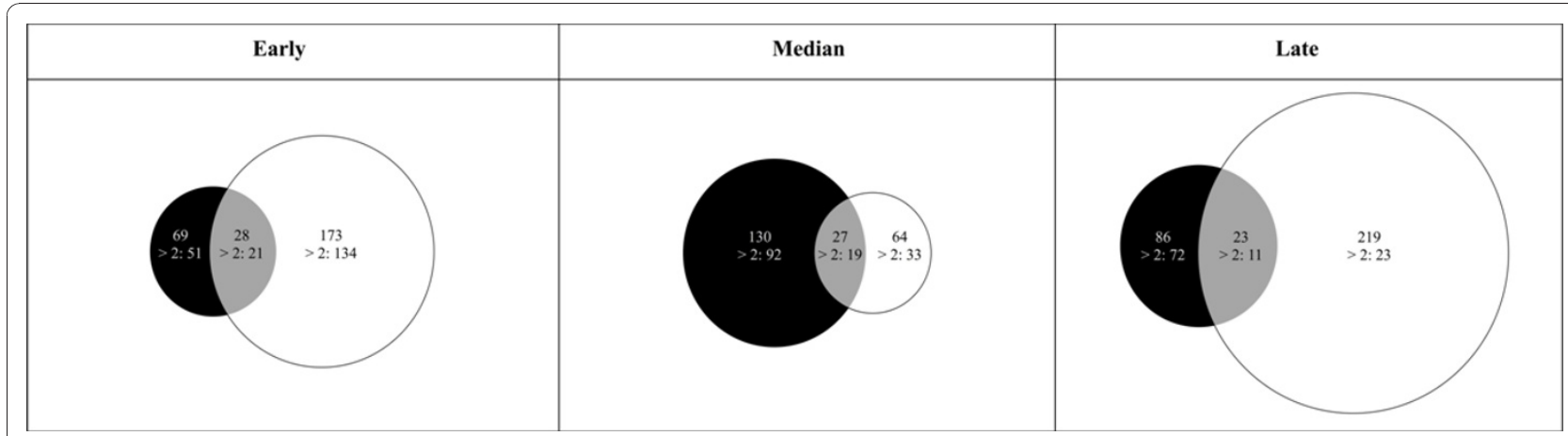

Figure 1 Characterisation of the transcriptomic response. A; Venn diagram representing mRNA transcripts differentially expressed over control during PGN-O111:B4 and PGN-K12 challenges throughout the time (early, median and late stage). The area of the circles is scaled to the number of transcripts (one way ANOVA $p<0.01$ ) and the fold change (FC $>2$ ) expressed in each stage. Black circles: $69,130,86$ number of transcripts differentially expressed under PGN-O111:B4 treatment. White circles: 173, 64, 219 number of transcripts differentially expressed under PGN-K12 challenge. 
Table 1 Summary of selected transcripts expressed after challenges with PGN-0111:B4

\begin{tabular}{|c|c|c|c|c|c|c|}
\hline \multirow[b]{2}{*}{ Antigen presenttion } & \multicolumn{2}{|c|}{ Early } & \multicolumn{2}{|c|}{ Median } & \multicolumn{2}{|c|}{ Late } \\
\hline & Mean & SD & Mean & SD & Mean & SD \\
\hline MHC class I heavy chain-1 & 4.92 & 2.35 & 3.27 & 1.67 & $\mathrm{n} / \mathrm{s}$ & $\mathrm{n} / \mathrm{s}$ \\
\hline Macrophage receptor MARCO & 2.07 & 0.56 & 5.02 & 1.75 & $\mathrm{n} / \mathrm{s}$ & $n / s$ \\
\hline Cysteine-rich protein 1 & -3.59 & 0.74 & $\mathrm{n} / \mathrm{s}$ & $\mathrm{n} / \mathrm{s}$ & $\mathrm{n} / \mathrm{s}$ & $n / s$ \\
\hline BPI binding protein & $\mathrm{n} / \mathrm{s}$ & $\mathrm{n} / \mathrm{s}$ & 11.93 & 5.78 & $\mathrm{n} / \mathrm{s}$ & $\mathrm{n} / \mathrm{s}$ \\
\hline \multicolumn{7}{|l|}{ Cell adhesion and proliferation } \\
\hline CD166 & 1.79 & 0.35 & 4.99 & 2.97 & 3.06 & 1.48 \\
\hline \multicolumn{7}{|l|}{ Cytokines and Chemokines } \\
\hline C-C chemokine receptor type 3 & 4.25 & 3.47 & $\mathrm{n} / \mathrm{s}$ & $\mathrm{n} / \mathrm{s}$ & $\mathrm{n} / \mathrm{s}$ & $\mathrm{n} / \mathrm{s}$ \\
\hline Chemokine receptor CXCR4 & $\mathrm{n} / \mathrm{s}$ & $\mathrm{n} / \mathrm{s}$ & -4.24 & 1.01 & $\mathrm{n} / \mathrm{s}$ & $\mathrm{n} / \mathrm{s}$ \\
\hline \multicolumn{7}{|l|}{ Cellullar defense response } \\
\hline $\begin{array}{l}\mathrm{N} \text {-acetylmuramoyl-L-alanine } \\
\text { amidase }\end{array}$ & -1.60 & 0.05 & 1.46 & 0.03 & 1.46 & 0.17 \\
\hline Peroxiredoxin 1-1 & -2.98 & 1.42 & 1.30 & 0.76 & 1.74 & 0.30 \\
\hline $\begin{array}{l}\text { Interleukin enhancer-binding } \\
\text { factor } 3\end{array}$ & $n / s$ & $\mathrm{n} / \mathrm{s}$ & 2.39 & 1.47 & $\mathrm{n} / \mathrm{s}$ & $\mathrm{n} / \mathrm{s}$ \\
\hline TNF decoy receptor & $n / s$ & $\mathrm{n} / \mathrm{s}$ & 11.42 & 3.86 & 12.09 & 10.98 \\
\hline NF-kappaB inhibitor alpha-3 & $n / s$ & $\mathrm{n} / \mathrm{s}$ & & 6.05 & $\mathrm{n} / \mathrm{s}$ & $\mathrm{n} / \mathrm{s}$ \\
\hline $\begin{array}{l}\text { Myeloid differentiation primary } \\
\text { response }\end{array}$ & $n / s$ & $\mathrm{n} / \mathrm{s}$ & $\mathrm{n} / \mathrm{s}$ & $\mathrm{n} / \mathrm{s}$ & 1.56 & 0.29 \\
\hline Phosphotyrosine SH2 domain & $\mathrm{n} / \mathrm{s}$ & $\mathrm{n} / \mathrm{s}$ & $\mathrm{n} / \mathrm{s}$ & $\mathrm{n} / \mathrm{s}$ & 2.86 & 1.17 \\
\hline Procathepsin L-1 & $\mathrm{n} / \mathrm{s}$ & $\mathrm{n} / \mathrm{s}$ & 4.11 & 1.67 & $\mathrm{n} / \mathrm{s}$ & $\mathrm{n} / \mathrm{s}$ \\
\hline Procathepsin L-2 & $\mathrm{n} / \mathrm{s}$ & $\mathrm{n} / \mathrm{s}$ & 3.47 & 1.28 & $\mathrm{n} / \mathrm{s}$ & $\mathrm{n} / \mathrm{s}$ \\
\hline Cathepsin B-2 & $\mathrm{n} / \mathrm{s}$ & $\mathrm{n} / \mathrm{s}$ & 3.36 & 2.29 & $\mathrm{n} / \mathrm{s}$ & $\mathrm{n} / \mathrm{s}$ \\
\hline Cathepsin D-2 & $\mathrm{n} / \mathrm{s}$ & $\mathrm{n} / \mathrm{s}$ & 3.99 & 0.25 & $\mathrm{n} / \mathrm{s}$ & $\mathrm{n} / \mathrm{s}$ \\
\hline Cathepsin C-1 & $\mathrm{n} / \mathrm{s}$ & $\mathrm{n} / \mathrm{s}$ & 3.28 & 1.16 & $\mathrm{n} / \mathrm{s}$ & $n / s$ \\
\hline Cathepsin C-2 & $\mathrm{n} / \mathrm{s}$ & $\mathrm{n} / \mathrm{s}$ & 5.14 & 5.30 & $\mathrm{n} / \mathrm{s}$ & $\mathrm{n} / \mathrm{s}$ \\
\hline \multicolumn{7}{|l|}{ MAPK/ERK } \\
\hline $\begin{array}{l}\text { Serine/threonine-protein } \\
\text { kinase } 2\end{array}$ & $n / s$ & $n / s$ & 5.03 & 2.65 & $n / s$ & $n / s$ \\
\hline MAPK/ERK kinase kinase 5-1 & $\mathrm{n} / \mathrm{s}$ & $\mathrm{n} / \mathrm{s}$ & -1.68 & 0.33 & $\mathrm{n} / \mathrm{s}$ & $\mathrm{n} / \mathrm{s}$ \\
\hline C-Jun protein & $\mathrm{n} / \mathrm{s}$ & $\mathrm{n} / \mathrm{s}$ & $\mathrm{n} / \mathrm{s}$ & $\mathrm{n} / \mathrm{s}$ & 3.99 & 1.62 \\
\hline MAPK/ERK kinase kinase 1-2 & $\mathrm{n} / \mathrm{s}$ & $\mathrm{n} / \mathrm{s}$ & $\mathrm{n} / \mathrm{s}$ & $\mathrm{n} / \mathrm{s}$ & 1.87 & 0.46 \\
\hline MAPK kinase 9-2 & $n / s$ & $\mathrm{n} / \mathrm{s}$ & $n / s$ & $n / s$ & 5.78 & 3.73 \\
\hline
\end{tabular}

Transcripts represented were firstly selected for expression level $(p<0.01)$ and then implication in biological processes related to PGN stimulation (immune/inflammatory responses) during PGN-O111:B4. n/s: not signal, Mean: Fold expression average $(n=3)$, SD: standard deviation.

form of MARCO, Cysteine-rich protein 1, that also recognises bacterial cell wall PAMP's was co-ordinately down-regulated [47]. Transcripts related to the inflammatory response were down regulated under both PGN challenges including for PGN-B4; N-acetylmuramoyl-Lalanine amidase (bactericidal activity), PGLYPR6 and peroxiredoxin (Table 1) and for PGN-K12; NF- $\kappa$ B inhibitor alpha-1 and arachidonate 5-lipoxygenase (Table 2). Microsomal glutathione S-transferase, a precursor for leukotriene and prostaglandin production [48] was down-regulated by both treatments. Interestingly, annexin A1-1 was strongly up-regulated (FC; 9.8) in response to $\mathrm{PGN}-\mathrm{K} 12$. This transcript has been suggested to have anti-inflammatory activity due to its phospholipase A2 (essential for inflammatory prostaglandin production) inhibitory activity [49] (Table 2 and Additional file 6).

\section{Median stage}

Of note at the median stage is that PGN-B4 induces a co-ordinated increase in pro-inflammatory and cellular defence activity with increased intensity (Table 1 and 2). Mediators of inflammatory prostaglandin production are up-regulated highlighted by increased arachidonate 5 lipoxygenase mRNA synthesis. In parallel, cathepsin transcripts (protease activity) $(n=6)$, PGLYPR6 (amidase) and the interleukin enhancer 3 mRNA (regulates interleukin production during infectious processes (e.g., [50]), were also up-regulated. PGN-K12 stimulation at this point is highlighted by a strong down-regulation of transcript diversity, including cell adhesion, defence response, cell homeostasis and metabolism, with almost all observed early stage transcripts returning to base-line conditions (Table 1 and 2). Potentially of importance is the up-regulation of the transcription factor CCAAT/ enhancer binding protein $\beta$ (C/EBP- $\beta$ ) mRNA by PGN$\mathrm{K} 12$. C/EBP- $\beta$ has been shown to be intimately linked to immune and inflammatory processes and regulates the transcription of the pro-inflammatory cytokine, interleukin-6. On the other hand, the tumour necrosis factor (TNF) decoy receptor, which inhibits apoptosis, and NF- $\kappa$ B inhibitor alpha-3 were strongly up-regulated in addition to an abrupt increase in BPI with PGN-B4.

Late stage

For PGN-B4 a defined response was observed after $12 \mathrm{~h}$ of stimulation where the prostaglandin endoperoxide synthase-2 (COX-2), and prostaglandin D synthase, both linked to the synthesis of inflammatory prostaglandins, were strongly up-regulated (Table 1). COX-2 (prostaglandin endoperoxide synthase-2) catalyses the conversion of arachidonic acid to prostaglandin $\left(\mathrm{PGH}_{2}\right)$ [51,52], and prostaglandin D synthase (PTGDS) catalyses the conversion of $\mathrm{PGH}_{2}$ to prostaglandin $\mathrm{D}_{2}\left(\mathrm{PGD}_{2}\right)[53,54]$. Signalling components for TLR pathways are also up-regulated by PGN-B4 including the MAPK pathways and myeloid differentiation primary response (MyD88) mRNA, an adapter protein between TLR and the transcription factor $\mathrm{NF}-\kappa \mathrm{B}$. Interestingly these components plus the serine/ threonine-protein kinase 2 are required to respond to microbial ligands [55]. TNF decoy receptor is maintained up-regulated highlighting the anti-apoptotic response of PGN-B4 activated macrophages. TNF- $\alpha$ is secreted into the culture medium as soon as $1 \mathrm{~h}$ after PGN treatment [MacKenzie et al, unpublished results]. In contrast to the strong inflammatory profile obtained for PGN-B4 the PGN-K12, response at $12 \mathrm{~h}$ appears related to biological themes associated with energy, protein metabolism and cellular homeostasis at a low level of intensity (Table 2 
Table 2 Summary of selected transcripts expressed after challenges with PGN-K12

\begin{tabular}{|c|c|c|c|c|c|c|}
\hline \multirow[b]{2}{*}{ Antigen presenttion } & \multicolumn{2}{|c|}{ Early } & \multicolumn{2}{|c|}{ Median } & \multicolumn{2}{|c|}{ Late } \\
\hline & Mean & SD & Mean & SD & Mean & SD \\
\hline MHC class I heavy chain-1 & 1.6 & 0.3 & 3.8 & 1.1 & 4.1 & 3.9 \\
\hline BPI binding protein & 3.4 & 2.5 & $n / s$ & $n / s$ & 1.5 & 0.6 \\
\hline Macrophage receptor MARCO & $n / s$ & $n / s$ & $n / s$ & $\mathrm{n} / \mathrm{s}$ & 0.4 & 1.8 \\
\hline \multicolumn{7}{|l|}{ Cell adhesion and proliferation } \\
\hline Fibronectin receptor beta & 11.6 & 11.3 & $n / s$ & $n / s$ & $n / s$ & $n / s$ \\
\hline CD2 binding protein 1-1 & 2.9 & 1.1 & $n / s$ & $\mathrm{n} / \mathrm{s}$ & $n / s$ & $n / s$ \\
\hline Matrix metalloproteinase 9 & 2.0 & 0.7 & $n / s$ & $\mathrm{n} / \mathrm{s}$ & -4.7 & 1.8 \\
\hline \multicolumn{7}{|l|}{ Cytokines and Chemokines } \\
\hline Cytokine receptor gamma chain & 1.7 & 0.5 & $n / s$ & $n / s$ & $n / s$ & $n / s$ \\
\hline CC chemokine SCYA110-1 & $n / s$ & $n / s$ & $n / s$ & $n / s$ & 1.2 & 0.1 \\
\hline \multicolumn{7}{|l|}{ Cellullar defense response } \\
\hline TNF receptor associated factor 1 & $n / s$ & $n / s$ & 4.6 & 4.1 & $n / s$ & $n / s$ \\
\hline NF-kappaB inhibitor alpha-1 & 4.6 & 4.3 & $n / s$ & $n / s$ & $n / s$ & $n / s$ \\
\hline Cathepsin C-3 & 2.8 & 2.3 & $n / s$ & $\mathrm{n} / \mathrm{s}$ & $n / s$ & $n / s$ \\
\hline Cathepsin D-1 & 3.2 & 2.8 & $n / s$ & $n / s$ & 1.6 & 0.5 \\
\hline Cathepsin D-2 & 3.7 & 3.6 & $\mathrm{n} / \mathrm{s}$ & $\mathrm{n} / \mathrm{s}$ & $n / s$ & $n / s$ \\
\hline \multicolumn{7}{|l|}{ MAPK/ERK } \\
\hline MAPK/ERK kinase kinase 6 & 1.7 & 0.3 & 2.1 & 0.5 & $n / s$ & $n / s$ \\
\hline Serine/threonine-protein kinase 2 & 2.9 & 2.2 & $n / s$ & $n / s$ & -1.2 & 0.1 \\
\hline Tyrosine-protein kinase FRK & $n / s$ & $n / s$ & $n / s$ & $n / s$ & 1.7 & 0.5 \\
\hline Tyrosine-protein kinase SYK & $n / s$ & $n / s$ & $n / s$ & $\mathrm{n} / \mathrm{s}$ & -2.0 & 1.4 \\
\hline \multicolumn{7}{|l|}{ Inflammatory response } \\
\hline Annexin A1-1 & 9.8 & 9.4 & $n / s$ & $\mathrm{n} / \mathrm{s}$ & 1.4 & 0.3 \\
\hline Microsomal glutathione S-transferase 3 & -1.6 & 0.2 & -1.4 & 0.2 & 1.2 & 0.1 \\
\hline Arachidonate 5-lipoxygenase-1 & -3.4 & 0.4 & $n / s$ & $n / s$ & $n / s$ & $n / s$ \\
\hline Prostaglandine D synthase & 1.3 & 0.1 & $n / s$ & $n / s$ & $n / s$ & $n / s$ \\
\hline Angiotensin I converting enzyme & 0.0 & $n / s$ & $n / s$ & $\mathrm{n} / \mathrm{s}$ & 1.2 & $n / s$ \\
\hline \multicolumn{7}{|l|}{ Cell homeostasis } \\
\hline Metallothionein A & -4.4 & 1.1 & $n / s$ & $n / s$ & 1.4 & 0.2 \\
\hline Heat shock 27 kDa protein-1 & 2.8 & 0.8 & $n / s$ & $\mathrm{n} / \mathrm{s}$ & -1.8 & 0.6 \\
\hline Heat shock 70 kDa protein 1 & 3.0 & 1.4 & $n / s$ & $n / s$ & -1.7 & 0.4 \\
\hline Glutathione reductase & 2.0 & 0.8 & $n / s$ & $\mathrm{n} / \mathrm{s}$ & -2.2 & 1.0 \\
\hline \multicolumn{7}{|l|}{ Cellular metabolism } \\
\hline Malate dehydrogenase, cytoplasmic & 2.1 & 0.6 & $n / s$ & $n / s$ & $\mathrm{n} / \mathrm{s}$ & $n / s$ \\
\hline Glucose-6-phosphate isomerase-1 & $n / s$ & $n / s$ & $n / s$ & $n / s$ & 2.4 & 1.7 \\
\hline ATP synthase factor 6 & 2.4 & 1.7 & $n / s$ & $\mathrm{n} / \mathrm{s}$ & $n / s$ & $n / s$ \\
\hline \multicolumn{7}{|l|}{ Transcription } \\
\hline Reverse transcriptase-like-2 & 2.4 & 1.7 & -2.7 & 0.6 & $n / s$ & $n / s$ \\
\hline CCAAT/enhancer binding protein beta & $n / s$ & $n / s$ & 7.0 & 2.6 & 1.4 & 0.5 \\
\hline \multicolumn{7}{|l|}{ Chromatin dis-assembly } \\
\hline Transposase-15 & -4.0 & 3.4 & $n / s$ & $n / s$ & -1.3 & 0.3 \\
\hline Transposase-56 & $n / s$ & $n / s$ & -3.4 & 0.5 & $n / s$ & $n / s$ \\
\hline G1/S-specific cyclin D2 & -3.1 & 2.0 & -3.6 & 1.4 & 1.5 & 0.4 \\
\hline
\end{tabular}

Transcripts represented were selected for expression level $(p<0.01)$ and then implication in biological processes related to PGN stimulation (immune/ inflammatory responses) during PGN-K12. n/s: no signal. Mean: Fold expression average $(n=3)$, SD: standard deviation.

and Additional file 8). These results imply close similarities with those previously obtained for trout macrophages activated with crude LPS [56-59] suggesting a common recognition mechanism distinct to that observed for PGN-B4.
From transcripts identified as differentially expressed and significantly up- or down-regulated (one-way ANOVA $p<$ 0.01 ) we selected sixteen transcripts from the late stage for qRT-PCR validation. All sixteen transcripts were significantly expressed between the two PGNs and significantly 
correlated when tested by qRT-PCR and Students-T test $(p<0.05)$; thereby confirming the microarray results. FC values obtain by microarray and qRT-PCR analyses are listed in the additional file 2 (Student $\mathrm{T}$ tests $p>0.05$ ).

\section{Functional categories are associated with combinations of PGN and time parameters}

Analysis of function using GO annotations revealed that most over-expressed transcripts were related to the immune response and GO functional categories are specifically influenced by a combinatorial PGN-Time effect (Chi-square with Yates correction, $p<0.01$, Figure 2). In the early stage, different GO categories expressed were PGN-dependent and include MHC class I receptor, lysozome, NF- $\kappa$ B cascade, peptidase activity, cell adhesion, ribosome, or chromatin assembly or disassembly (Figure 2). At the median stage the intensity of the PGN-B4 response is highlighted by a set of biological processes specifically associated to the immune response whereas only two GO classes, cell adhesion and negative regulation of cell proliferation, were represented with PGN-K12 (Figure 2). At the late stage an inverse correlation was observed where peptidase activity, complement activation, cell homeostasis, and mitochondrial electron transport were highly represented with PGN-K12 and NF- $\kappa$ B cascade, proteinMAPK cascade, and ribosome related to the PGN-O111: B4 response (Figure 2). Remarkably, cell wall catabolism was only observed with PGN-K12 and not during PGNO111:B4 challenge (Figure 2).

\section{Characterisation of the prostaglandin response (time course and dose response of PGN challenges)}

Both COX-2 and PTGDS were identified by microarray analyses as differentially expressed between the two PGNs, therefore we measured both $\mathrm{PGE}_{2}$ and $\mathrm{PGD}_{2}$ release into the culture supernatant and in parallel
COX-2 and PTGDS mRNA abundance by qRT-PCR. Analyses were done both in respect to response to PGN-B4 and PGN-K12 over time (30 min, 1, 3, 6 and $12 \mathrm{~h}$; Figure 3) and subsequently as a dose response $(0.1,1$ and $10 \mu \mathrm{g} / \mathrm{mL}$; Figure 4).

Time course response assay $(0,30 \mathrm{~min}, 1,3,6$, and $12 \mathrm{hrs}$ of PGN challenges)

COX-2 mRNA expression is strongly regulated by PGNB4 over time followed by a significant increase in $\mathrm{PGE}_{2}$ secretion into the culture medium. Stimulation with PGN-K12 results in an increase of mRNA abundance at $1 \mathrm{~h}$ (two way ANOVA, $\mathrm{F}_{5,35}=8.678, p<0.05$, Figure 3a, Additional file 12) and a more gradual accumulation of $\mathrm{PGE}_{2}$ in the culture medium in comparison with PGN-B4. The dynamics of PTGDS mRNA expression was time dependent (two way ANOVA, $F_{5,35}=4.584$, $p<0.05$, Figure 3a, Additional file 12) showing changes a few minutes after stimulation with both PGNs (30 min) and a strong increase $1 \mathrm{~h}$ post-treatment (Figure 3a). The release of $\mathrm{PGD}_{2}$ was significantly different (increasing) in PGN-B4 treated macrophages $6 \mathrm{~h}$ after stimulation. Differences observed between $\mathrm{PGE}_{2}$ and $\mathrm{PGD}_{2}$ release are correlated to both time and treatment (two way ANOVA, $\mathrm{F}_{10,54}=4.553, p<0.05$, Figure 3b, Additional file 12) where $\mathrm{PGD}_{2}$ has a low response, concentrations in the range of $1-14 \mathrm{pg} / \mathrm{mL}$, when compared with the $\mathrm{PGE}_{2}$ secretion, $>200 \mathrm{pg} / \mathrm{mL}$. $\mathrm{PGE}_{2}$ and $\mathrm{PGD}_{2}$ liberation patterns were strongly influenced by the interaction between PGN and time (two way ANOVA, $\mathrm{F}_{10,54}=2.522, p<0.05$, Figure 3b, Additional file 12).

\section{Dose response assay $(0.1,1$, and $10 \mu \mathrm{g} / \mathrm{mL}$ of PGN 0111:} B4 and K12)

In dose response assays the expression pattern of COX2 mRNA induction was both dose and PGN-dependent

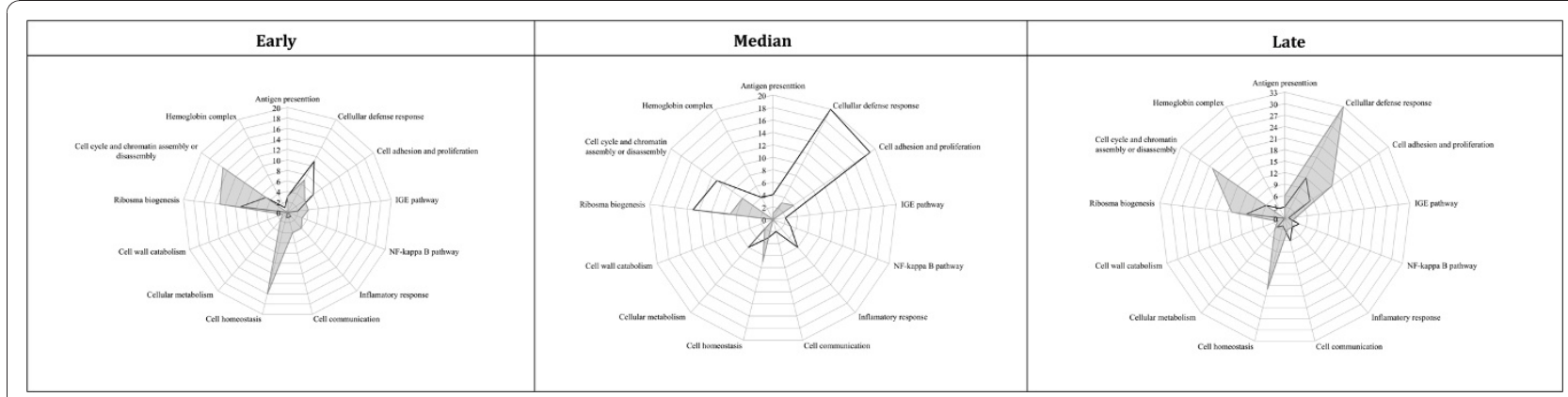

Figure 2 Qualitative and quantitative representations of biological processes (GO) over represented during challenges. Qualitative and quantitative representations of over expressed GO categories (Chi-square with Yates correction $p<0.05$ ). The corners of the spider-web maps represent biological processes identified in the $\mathrm{GO}$ analysis. Different numbers of transcripts were grouped in each biological process. The continuous mark lines (black or grey) represent the different number of transcripts in each biological process. The differences in the shape of the GO pattern (continuous mark line) are due to divergence in the number of transcripts grouped to each Gene Class (biological process) under both PGN challenges; the black line shows the GO pattern for PGN-O111:B4 and the grey line shows the GO pattern for PGN-K12 treatment. 
(two way ANOVA, $\mathrm{F}_{5,18}=5.824, p<0.05$, Figure 4a, Additional file 12). In figure $4 \mathrm{a}$, a peak of COX-2 expression was registered at $10 \mu \mathrm{g} / \mathrm{mL}$ of PG-B4. Interestingly, PGN-K12 stimulation generated a lower expression of COX-2 mRNA (10 $\mu \mathrm{g} / \mathrm{mL} ;>50$ fold) when compared to PGN-B4 although at a dose of $1 \mu \mathrm{g} / \mathrm{mL}$ fold changes are similar for both PGNs (Figure 4a). This is reflected in $\mathrm{PGE}_{2}$ liberation where $10 \mu \mathrm{g} / \mathrm{mL}$ of PGNB4 generated a strong response ( $>600$ fold increase; PGN-interaction, two way ANOVA, $F_{2}, 48=182.588$, $p<0.05$, Additional file 12) that correlated to increased COX-2 mRNA abundance and all other concentrations for both PGNs induced similar responses ( $>50$ fold). The liberation pattern of $\mathrm{PGD}_{2}$ was significantly dependent upon PGN type, and showed a single increase at $10 \mu \mathrm{g} / \mathrm{mL}$ with PGN-B4 (Two way ANOVA, $\mathrm{F}_{2,48}=$ 4.588, $p<0.05$, Additional file 12). Surprisingly this is not mirrored in PTGDS mRNA abundance levels where PTGDS mRNA is significantly up-regulated by PGN-
$\mathrm{K} 12$ at 0.1 and $1 \mu \mathrm{g} / \mathrm{mL}$ and PGN-B4 at $1 \mu \mathrm{g} / \mathrm{mL}$ (Figure 4b, Additional file 12).

\section{Discussion}

In recent studies on trout macrophages, peptidoglycan (PGN-B4) was identified as a major pro-inflammatory component of crude LPS preparations in which TLR4 and canonical TLR2 signalling pathways were discarded as potential recognition systems for peptidoglycans [9]. As structural differences in PGN peptide moieties from different bacterial-strains have been shown to modulate host responses in both Drosophila and mammals $[32,36,38]$ we investigated, a priori with targeted microarray analysis, the effects of two different PGNs from different strains of E. coli, O111:B4 and K12. These different serological features have been shown to affect the host immune response [60]. A systematic dissection of the impact of (combinations of) culture parameters (time and treatment) revealed a significant re-modelling

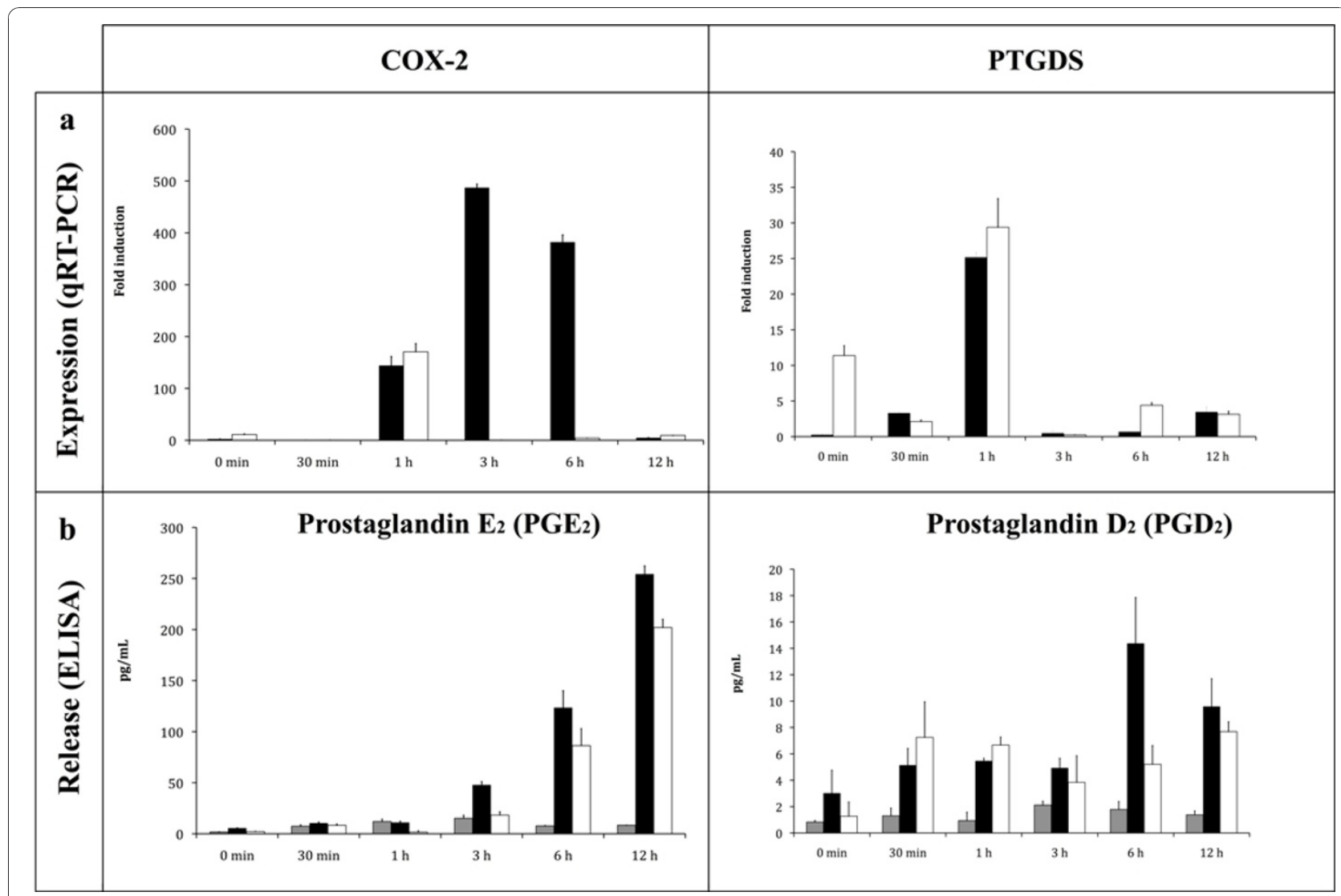

Figure 3 Temporal characterisation of the prostaglandin response. Time course response to macrophages stimulated during 0,30 min, 1, 3 , 6 , and $12 \mathrm{~h}$ with $10 \mathrm{\mu g} / \mathrm{mL}$ of PGN O111:B4 and K12. Experiments were performed in independent groups of PGN-stimulated $(\mathrm{n}=3)$ or control macrophage cultures $(n=9)$. a) COX-2 and PTGDS mRNA abundance over time in response to PGN-B4 (black bar) or PGN-K12 (white bar). Were observed significative differences in the mRNA abundance between the times and treatments (PGNs) in both genes (two way ANOVA $p<0.01$ ). b) $P G E_{2}$ and $P \mathrm{PD}_{2}$ release $(\mathrm{pg} / \mathrm{mL}$ ) stimulated by PGN-O111:B4 (black bars), PGN-K12 (white bars) and control (grey bars) into the culture medium ( $n=3 /$ treatment). Were observed significative differences in the release between the times and treatments (PGNs or control) by both prostaglandin (two way ANOVAs $p<0,01$ ). The results are presents as fold change relative to $18 \mathrm{~S}$ abundance and \pm std deviation. 


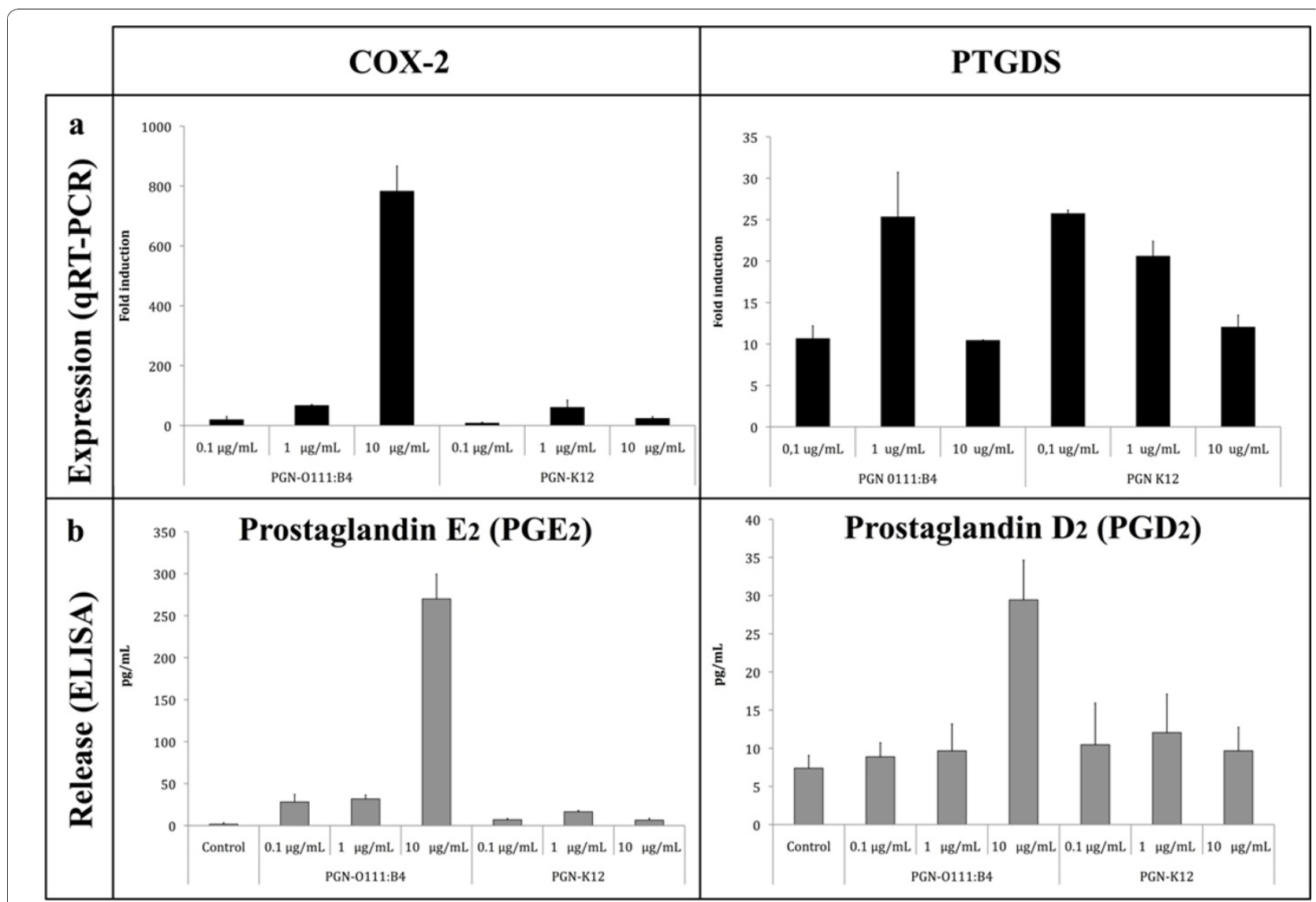

Figure 4 Concentration dependence of the prostaglandin response. Dose response $(0.1,1$, and $10 \mu \mathrm{g} / \mathrm{mL})$ of trout macrophages to PGN 0111:B4 and K12 challenge. Experiments were performed overnight in independent macrophage cultures $(n=3)$. a) COX-2 and PTGDS mRNA abundance (black bar) in response to different doses of PGN-O111:B4 or PGN-K12 (0.1, 1, $10 \mu \mathrm{g} / \mathrm{mL}$ ). Were observed significative differences in the mRNA abundance between different doses and treatments (PGNs) in both genes (two way ANOVAs $p<0.01$ ). b) $P G E_{2}$ and $P G D_{2}$ release $(\mathrm{pg} / \mathrm{mL})$ into the culture medium (grey bars). Were observed significative differences in the release between doses and treatments (PGNs or control) by both prostaglandins (two way ANOVAs $p<0.01$ ). The results are presented as fold change relative to $18 \mathrm{~S}$ abundance and mean \pm std deviation.

of the trout macrophage transcriptome highlighting the divergence of the response to the two different PGNs (PGN-B4 vs. PGN-K12). As there were no other known variables, the differences in the transcriptomic profile are assumed to be solely due to the structure of the different PGNs and therefore differential recognition of those by the macrophages. This assumption is supported by the variation in transcript number (Figure 1a, 2), their intensities (Figure 1a,b), and diversity (Table 1 and 2). In fish, modifications in the transcriptomic profile have been observed in response to environmental changes, stress and maintenance of the steady state of transcriptional activity [61,62], or bidirectional transcriptomic remodelling to inflammatory stimuli [56,63-67]; however, our data emphasises that macrophages respond differentially to highly similar bacterial PGNs resulting in a directed response i.e. prostaglandin release or a more generalised 'state of activation'.
In fish, the shift from a steady state to a functional inflammatory state, i.e. secretion of pro-inflammatory cytokines or $\mathrm{PGE}_{2}$, in trout macrophages stimulated with crude LPS preparations has been shown to be driven mainly by gram negative PGN, where DNA and RNA and ultra-pure LPS preparations are unable to induce mRNA expression of pro-inflammatory cytokines $[9,68]$. Our microarray analysis identified differential regulation of both prostaglandin D-synthase (PTGDS) and prostaglandin endoperoxide synthase-2 (COX-2) that are directly involved in eicosanoid production; $\mathrm{PGD}_{2}$ and $\mathrm{PGE}_{2}$ respectively [51,53] (Table 1 and 2). COX-2 is regulated in macrophage/monocyte cell types and is responsible for inflammatory prostaglandin, $\mathrm{PGE}_{2}$, synthesis from arachidonic acid, and is involved in cellular or tissue damage generated in acute and/or chronic inflammatory states [69]. PTGDS metabolises $\mathrm{PGH}_{2}$ to $\mathrm{PGD}_{2}$, $[53,54,70,71]$ where $\mathrm{PGD}_{2}$ plays a role 
during the injury process as vasodilator/constrictor or as potent inflammatory mediator $[72,73]$. However, the action of $\mathrm{PGD}_{2}$ in fish as a mediator of the immune response is undefined. Downstream analyses, qRT-PCR and prostaglandin release, of both COX-2 and PTGDS mRNA regulation and $\mathrm{PGH}_{2}$ and $\mathrm{PGD}_{2}$ concentration in supernatants reveals a strong correlation, both time and dose-dependent, between PGN-type (B4 vs K12), mRNA abundance and inflammatory outcome (Figure 4). PGN-B4 is clearly a more potent regulator of the COX2 mRNA/PGE 2 pathway where the activation threshold for de novo synthesis of COX-2 is $10 \mu \mathrm{g} / \mathrm{mL}$ of PGN-B4. Interestingly this threshold concentration has also been observed on numerous occasions for pro-inflammatory cytokine mRNA synthesis in trout macrophages $[9,39,46,68]$. On the other hand, PTGDS mRNA synthesis appears as more dose sensitive for both PGNs with a similar temporal expression pattern suggestive of a different signal transduction mechanism. However PGN-B4 stimulation at $10 \mu \mathrm{g} / \mathrm{mL}$ results in higher $\mathrm{PGD}_{2}$ secretion. The regulation and biological effects of $\mathrm{PGE}_{2}$ and $\mathrm{PGD}_{2}$ secretion in inflammatory responses in fish clearly warrant more investigation.

In Drosophila the biological activity of a large panel of natural and synthetic DAP-PGN showed significant variability in their stimulatory capacity and immune response [74] and PGRP (peptidoglycan recognition protein) deficient Drosophila are more susceptible to bacterial infections [75]. In human monocytes exposed to synthetic muropeptides (peptide moiety of PGNs), TNF- $\alpha$ mRNA expression and release was highly dependent upon structural modifications between peptides [38]. Thus inflammatory outcomes are modified in accordance to sensitivity to peptidoglycan structure. Such sensitivity is likely conferred by the participation of different PRRs, PAMP-PRR interactions or the accumulative signalling intensity (i.e. threshold) of the group of PRRs involved in recognition.

Peptidoglycan recognition in mammals is mainly facilitated by three different PRR families; TLR2 (gram positive peptidoglycan), NOD2 and PGRPs all of which can bind peptidoglycans $[35,75,76]$. TLR2 has been described in fish species [77] although stimulation with lipoprotein (Pam3CSK4), a classical TLR2-ligand, does not stimulate an inflammatory response in our macrophage model [9]. However MyD88, an adaptor molecule involved in the classical Drosophila or mammalian Toll signalling cascades, which together with the receptor associated kinase (IRAK) and TNF activated factor (TRAF6) allow $\mathrm{NF}-\kappa \mathrm{B}$ translocation to the nucleus (promoting expression of inducible inflammatory cytokines such as TNF- $\alpha$ ) during gram-negative bacterial infection [46,78-80] was specifically up-regulated during PGNB4 stimulation. This suggests TLR involvement in the PGN-mediated inflammatory response in trout macrophages. Concerning PGRPs, PGRP-2, -5 and -6, have been shown in the zebrafish to play an essential role in defence during bacterial infections [30] and in the trout PGRP-2 responds to PGN-B4 [9]. In this study we also identified PGLYRP-6 (up-regulated; PGN-B4) suggesting that the PGRPs also play a role in specificPGN recognition and this may be conserved throughout the fishes.

In contrast to the specific directed response obtained from PGN-B4 stimulation, PGN-K12 did not elicit a clear functional response at the level of the macrophage transcriptome or release of inflammatory mediators. A wide diversity of transcripts were activated although at a relatively low level. These results are similar to those previously observed for stimulation with crude LPS preparations in trout macrophages [[56], Boltaña et al., unpublished data] where both preparations can stimulate the release of TNF- $\alpha$ into the culture medium [[68], Roher et al., unpublished data]. Interestingly, TNF receptor associated factor 1 was specifically induced by PGNK12. This transcript encodes a receptor-protein involved in the activity of apoptotic pathways mediated by TNF- $\alpha$ [80-82], however, we did not detect apoptosis during the experimental period [MacKenzie et al, unpublished data]. Moreover, the gene ontology category cell wall catabolism was consistently over-expressed throughout PGN-K12 treatment (Figure 2a,b) supporting the existence of a strong transduction signal generated by PGN-K12.

\section{Conclusions}

Our data highlights the significant differences observed in macrophages responding to two PGNs derived from different serotypes of the same bacteria. Responses at the level of the transcriptome and the inflammatory outcome (prostaglandin synthesis) highlight the different sensitivity of the macrophage to slight differences (serotype) in peptidoglycan structure. Such divergent responses are likely to involve differential receptor sensitivity to ligands or indeed different receptor types. Such changes in biological response will likely reflect upon pathogenicity of certain serotypes and the development of disease.

\section{Additional material}

Additional file 1: Specific primers used for quantitative qRT-PCR (sequence and accession number).

Additional file 2: Comparison of expression data for selected transcripts obtained from microarray analyses and qRT-PCR validation. The results are presented as fold change relative to $18 \mathrm{~S}$ abundance and mean \pm std deviation.

Additional file 3: Description of PGN $(0111 ; B 4)$ regulated transcripts/genes over the control (all cDNAs on the array) at early stage $(1 \mathrm{~h})$. 


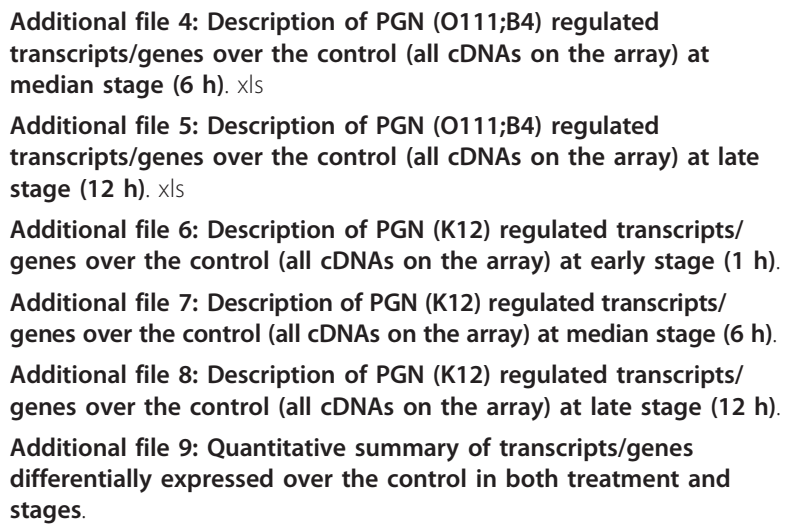

Additional file 11: Summary of ANCOVA analysis for common slope of regression and adjusted means examining differences in intensity and magnitude of the transcriptomic response at different times $(1,6$ and $12 \mathrm{~h} ; \mathrm{n}=68)$.

Additional file 12: Summary of multiple comparisons of two way ANOVAS.

\section{Abbreviations}

PAMPs: pathogen-associated molecular patterns; PGN: peptidoglycans; PGRPs: peptidoglycan recognition proteins; GDE: differentially expressed genes; COX-2: Cyclooxygenase 2; PTGDS: prostaglandin D synthase.

\section{Acknowledgements}

This study was supported by the Consolider-Ingenio Programme 2010, project CSD2007-0002 funded by the Spanish Ministry of Science and Education, Spain to SM.

\section{Author details}

'Institute of Biotechnology and Biomedicine, Universitat Autónoma de Barcelona, 08193 Barcelona, Spain. ${ }^{2}$ Departamento de Biologia, Universidad de Santiago de Chile, Santiago de Chile, Chile. ${ }^{3}$ Great Lakes WATER Institute, 600 E. Greenfield Ave., Milwaukee, WI 53204, USA.

\section{Authors' contributions}

SM, SB and FG participated in the conception of the experimental design. SB and SM carried out the analysis. SB, FRL and DM performed microarray experiments. SB edited expression data, carried all statistical analysis and validated array data with $\mathrm{QRT}$-PCR. SB and SM wrote the manuscript and FG corrected it. All listed authors edited the manuscript. All authors read and approved the manuscript.

Received: 16 June 2010 Accepted: 14 January 2011 Published: 14 January 2011
References

1. Kopp E, Medzhitov R: Recognition of microbial infection by Toll-like receptors. Curr Opin Immunol 2003, 15:396-401.

2. Kabelitz D, Medzhitov R: Innate immunity cross-talk with adaptive immunity through pattern recognition receptors and cytokines. Curr Opin Immunol 2007, 19:1-3.

3. Gupta D, Kirkland TN, Viriyakosol S, Dziarski R: CD14 Is a Cell-activating Receptor for Bacterial Peptidoglycan. J Biol Chem 1996, 271(38):23310-23316

4. Dziarski R, Tapping Rl, Tobias PS: Binding of Bacterial Peptidoglycan to CD14. J Biol Chem 1998, 273(15):8680-8690.

5. Dziarski R, Viriyakosol S, Kirkland TN, Gupta D: Soluble CD14 Enhances Membrane CD14-Mediated Responses to Peptidoglycan: Structural Requirements Differ from those for Responses to Lipopolysaccharide. Infect Immun 2000, 68(9):5254-5260.

6. Schrijver IA, Melief MJ, Eulderink F, Hazenberg MP, Laman JD: Bacterial Peptidoglycan Polysaccharides in Sterile Human Spleen Induce Proinflammatory Cytokine Production by Human Blood Cells. J Infect Dis 1999, 179:1459-1468.

7. Rabehi L, Irinopoulou T, Cholley B, Heaffner-Cavaillon N, Carreno MP: GramPositive and Gram-Negative Bacteria Do Not Trigger Monocytic Cytokine Production through Similar Intracellular Pathways. Infect Immun 2001, 69(7):4590-4599.

8. Hiev DB, Liarte CQ, Mackenzie S, Goetz FW: Activation of rainbow trout (Oncorhynchus mykiss) mononuclear phagocytes by different pathogen associated molecular pattern (PAMP) bearing agents. Mol Immunol 2005, 42:1215-1223.

9. Mackenzie S, Roher N, Boltaña S, Goetz FW: Peptidoglycan, not endotoxin, is the key mediator of cytokine gene expression induced in rainbow trout macrophages by crude LPS. Mol Immunol 2010, 47:1450-1457.

10. Dziarski R, Gupta D: Role of MD-2 in TLR2-and TLR4-mediated recognition of Gram-negative and Gram-positive bacteria and activation of chemokine genes. Innate Immun 2000, 6:401-405.

11. Dziarski R, Gupta D: Staphylococcus aureus Peptidoglycan Is a Toll-Like Receptor 2 Activator: a Reevaluation. Infect Imm 2005, 78(8):5212-5216.

12. Wang JE, Dahle MK, McDonald M, Foster SJ, Aasen AO, Thiemermann C: Peptidoglycan and lipoteichoic acid in gram-positive bacterial sepsis: receptors, signal transduction, biological effects, and sinergismo. Shock 2003, 20(5):402-414.

13. Xu Z, Dziarski R, Wang Q, Swartz K, Sakamoto KM, Gupta D: Bacterial Peptidoglycan-Induced tnf- Transcription Is Mediated Through the Transcription Factors Egr-1, Elk-1, and NF-. J Immunol 2001, 167(12):6975.

14. Weidemann B, Schletter J, Dziarski R, Kusumoto S, Stelter F, Rietschel ET, Flad HD, Ulmer AJ: Specific Binding of Soluble Peptidoglycan and Muramyldipeptide to CD14 on Human Monocytes. Infect Imm 1997, 65(3):858-864.

15. Dziarski R, Tapping Rl, Tobias PS: Binding of Bacterial Peptidoglycan to CD14. J Biol Chem 1998, 273(15):8680-8690.

16. Gupta D, Wang Q, Vinson CH, Dziarski R: Bacterial Peptidoglycan Induces CD14-dependent Activation of Transcription Factors CREB/ATF and AP-1. J Biol Chem 1999, 274(20):14012-14020.

17. Mathison JC, Tobias PS, Wolfson E, Ulvevitch RJ: Plasma lipopolysaccharide (LPS)-Binding protein. A Key Component in macropophage Recognition of Gram-Negative LPS. J Immunol 1992, 149(1):200-206.

18. Dziarski R: Recognition of bacterial peptidoglycan by the innate immune system. Cell Mol Life Sci 2003, 60:1793-1804.

19. Schwandner R, Dziarski R, Wesche $H$, Rothe M, Kirschning CJ: Peptidoglycan-and lipoteichoic acid-induced cell activation is mediated by toll-like receptor 2. J Biol Chem 1999, 274(25):17406-17419.

20. Schröder N, Morath S, Alexander C, Hamann L, Hartung T, Zahringer U, Gobel U, Weber J, Schumann RRalf: Lipoteichoic Acid (LTA) of Streptococcus pneumoniae and Staphylococcus aureus Activates Immune Cells via Toll-like Receptor (TLR)-2, Lipopolysaccharide-binding Protein (LBP), and CD14, whereas TLR-4 and MD-2 Are Not Involved. J Biol Chem 2003, 278(18):15587-15594.

21. Chamaillard M, Girardin S, Viala J, Philpott D: NODs, Nalps and Naip: intracellular regulators of bacterial-induced inflammation. Cell Microbiol 2003, 5:581-592.

22. Girardin SE, Boneca IG, Viala J, Chamaillard M, Labigne A, Thomas G, Philpott DJ, Sansonetti PJ: Nod2 Is a General Sensor of Peptidoglycan 
through Muramyl Dipeptide (MDP) Detection. J Biol Chem 2003, 278(11):8869-8872.

23. Girardin SE, Boneca IG, Carneiro LA, Antignac A, Jehanno M, Viala J, Tedin K, Taha MK, Labigne A, Zaehringer U, Coyl AJ, Di Stefano PS, Bertin J, Sansonetti PJ, Philpott DJ: Nod1 Detects a Unique Muropeptide from Gram-Negative Bacterial Peptidoglycan. Science 2003, 300:1584-1587, 2003.

24. Inohara N, Ogura Y, Fontalba A, Gutierrez O, Pons F, Crespo J, Fukase K, Inamura S, Kusumoto S, Hashimoto M, Foster SJ, Moran AP, FernandezLuna JS, Nuñez G: Host Recognition of Bacterial Muramyl Dipeptide Mediated through NOD2. J Biol Chem 2003, 278:5509-5512.

25. Kang D, Liu G, Lundstrom A, Gelius E, Steiner H: A peptidoglycan recognition protein in innate immunity conserved from insects to humans. Proc Natl Acad Sci USA 1998, 95:10078-10082.

26. Werner T, Liu G, Kang D, Ekengren S, Steiner H, Hultmark D: A family of peptidoglycan recognition proteins in the fruit fly Drosophila melanogaster. Proc Natl Acad Sci USA 2000, 97:13772-13777.

27. De Gregorio E, Spellman PT, Rubin GM, Lemaitre B: Genome-wide analysis of the Drosophila immune response by using oligonucleotide microarrays. Proc Natl Acad Sci USA 2001, 98:12590-12595.

28. De Gregorio E, Spellman P, Tzou P, Rubin GM, Lematrie B: The Toll and Imd pathways are the major regulators of the immune response in Drosophila. EMBO Journal 2002, 21(11):2568-2579.

29. Boutros M, Agaisse H, Perrimon N: Sequential Activation of Signaling Pathways during Innate Immune Responses in Drosophila. Dev Cell 2002, 3:711-722.

30. Li X, Wang S, Qi J, Echtenkamp SF, Chatterjee R, Wang M, Boons G, Dziarski R, Gupta D: Zebrafish Peptidoglycan Recognition Proteins Are Bactericidal Amidases. Nature Rev Immunol 2007, 2:725-734.

31. Ghuysen JM: Use of Bacteriolytic Enzymes in Determination of Wall Structure and Their Role in Cell Metabolism. Bacteriol Rev 1968, 32(4):425-464.

32. Schleifer $\mathrm{KH}$, Kandler O: Peptidoglycan types of bacterial cell walls and their taxonomic implications. Bacteriol Rev 1972, 36:407-77.

33. Jenni R, Berger-Bächi B: Teichoic acid content in different lineages of Staphylococcus aureus NCTC832. Arch Microbiol 1998, 170:171-178.

34. Deininger S, Stadelmaier A, Von Aulock S, Morath S, Schmidt RR, Hartung T: Definition of structural prerequisites for lipoteichoic acid-inducible cytokine induction by synthetic derivatives. J Immunol 2003, 170:4134-4138.

35. Boneca IG: The role of peptidoglycan in pathogenesis. Curr Opin Microbiol 2005, 8:46-53.

36. Kumar S, Roychowdhury A, Ember B, Wang Q, Guan R, Mariuzza RA Boons GJ: Selective recognition of synthetic lysine and mesodiaminopimelic acid-type peptidoglycan fragments by human peptidoglycan recognition proteins. J Biol Chem 2005, 280:37005-37012.

37. Wolfert MA, Murray TF, Boons GJ, Moore JN: The Origin of the Synergistic Effect of Muramyl Dipeptide with Endotoxin and Peptidoglycan. J Biol Chem 2002, 277(42):39179-39186.

38. Wolfert MA, Roychowdhury A, Boons GJ: Modification of the Structure of Peptidoglycan Is a Strategy To Avoid Detection by Nucleotide-Binding Oligomerization Domain Protein 1. Infect Immun 2007, 75(2):706-713.

39. Mackenzie S, Planas JV, Goetz FW: LPS-stimulated expression of a tumor necrosis factor-alpha mRNA in primary trout monocytes and in vitro differentiated macrophages. Dev Comp Immunol 2003, 27:393-400.

40. Koskinen $\mathrm{H}$, Pehkonen $\mathrm{P}$, Vehniainen $\mathrm{E}$, Krasnov $\mathrm{A}$, Rexroad $\mathrm{C}$, Afanasyev $\mathrm{S}$, Molsa $H$, Oikari A: Response of rainbow trout transcriptome to model chemical contaminants. Biochem Biophys Res Commun 2004, 320:745-753.

41. Krasnov A, Koskinen $\mathrm{H}$, Pehkonen $\mathrm{P}$, Rexroad CE, Afanasyev S, Molsa $\mathrm{H}$ : Gene expression in the brain and kidney of rainbow trout in response to handling stress. BMC Genomics 2005, 6(1):3-18.

42. Cleveland WS, Grosse E, Shyu WM: Local regression models. In Statistical Models. Edited by: Chambers JM, S TJHE. Pacific Grove, Wadsworth and rooks/Cole; 1999:309-376.

43. Storey JD, Tibshirani R: Statistical significance for genomewide studies. Proceedings of the National Academy of Sciences of the United States of America 2003, 100(16):9440-9445.

44. Ashburner M, Ball CA, Blake JA, Botstein D, Butler H, Cherry JM, Davis AP, Dolinski K, Dwight SS, Eppig JT, Harris MA, Hill DP, Issel-Tarver L, Kasarskis A, Lewis S, Matese JC, Richardson JE, Ringwald M, Rubin GM, Sherlock G: Gene ontology: tool for the unification of biology. The Gene Ontology Consortium. Nat Genet 2000, 25(1):25-29.

45. Pfaffl MW: A new mathematical model for relative quantification in realtime RT-PCR. Nucleic Acids Res 2001, 29:45-53.

46. Iliev DB, Roach KC, Mackenzie S, Planas JV, Goetz FW: Endotoxin recognition: In fish or not in fish? FEBS Letters 2005, 579:6519-6528.

47. Kraal G, Luc JW, Laan V, Eloma O, Tryggvason K: The macrophage receptor MARCO. Microbes Infect 2000, 2:313-316.

48. Hebert $H$, Jegerschöld $C$ : The structure of membrane associated protein in eicosanoid and glutathione metabolism as determined by electron crystallography. Curr Opin Struc Biol 2007, 17(4):396-404.

49. Wallner BP, Mattaliano RJ, Hession C, Cate RL, Tizard R, Sinclair LK, Foeller C, Chow EP, Browning JL, Ramachandran KL, Pepinsky B: Cloning and expression of human lipocortin, a phospholipase $\mathrm{A} 2$ inhibitor with potential anti-inflammatory activity. Nature 1986, 320:77-81.

50. Saunders L, Perkins R, Balachandran D, Michaels S, Ford R, Mayeda R, Barber A: Characterization of two evolutionarily conserved, alternatively spliced nuclear phosphoproteins, NFAR-1 and -2 , that function in mRNA processing and interact with the double-stranded RNAdependent protein kinase, PKR. J. Biological Chem 2001, 276:32300-32312.

51. Hla T, Neilson K: Human cyclooxygenase-2 cDNA. Proc Natl Acad Sci USA $1992,89: 7384-7388$

52. Tazawa R, Xu XM, Wu KK, Wang LH: Characterization of the Genomic Structure, Chromosomal Location and Promoter of Human Prostaglandin H Synthase-2 Gene. Biochem Bioph Res Co 1994, 203(1):190-199.

53. Shimizu T, Yamamoto S, Hayaishi O: Purification and properties of prostaglandin D synthetase from rat brain. J Biol Chem 1979, 254:5222-5228.

54. Nagata A, Suzuki Y, Igarashi M, Eguchi N, Toho H, Urade Y, Hayaishi O: Human brain prostaglandin D synthase has been evolutionarily differentiated from lipophilic-ligand carrier proteins. Proc. Nati. Acad. Sci. USA 1991, 88:4020-4024.

55. Kambris Z, Jang BS, Nam IH, Romeo HJ, Takahashi Y, Lee K, Ueda WJ, Lemaitre $B$ : Drosophila immunity: a large-scale in vivo RNAi screen identifies five serine proteases required for Toll activation. Curr Biol 2006, 16:808-813.

56. Mackenzie S, Balasch JC, Novoa B, Ribas L, Roher N, Krasnov A, Figueras A: Comparative analysis of the acute response of the trout, O. mykiss, head kidney to in vivo challenge with virulent and attenuated infectious hematopoietic necrosis virus and LPS-induced inflammation. BMC Genomics 2008, 9:141-156.

57. Goetz FW, Planas JV, Mackenzie S: Tumor necrosis factors. Dev Comp Immunol 2004, 28:487-497.

58. Mackenzie S, Montserrat N, Mas M, Acerete L, Tort L, Krasnov A, Goetz FW, Planas JV: Bacterial lipopolysaccharide induces apoptosis in the trout ovary. Reprod Biol Endocrin 2006, 4:46-58.

59. Mackenzie S, lliev D, Liarte C, Koskinen H, Planas JV, Goetz FW, Molsä H, Krasnov A, Tort L: Transcriptional analysis of LPS-stimulated activation of trout (Oncorhynchus mykiss) monocyte/macrophage cells in primary culture treated with cortisol. Molec Immun 2006, 43(9):1340-1348.

60. Barclay GR, Scott BB: Serological Relationships between Escherichia coli and Salmonella smooth- and rough-mutant lipopolysaccharides as revealed by enzyme-linked immunosorbent assay for human immunoglobulin G Antiendotoxin Antibodies. Innate Immun 1987, 55(11):2706-2714

61. Bayne CJ, Gerwick L, Wheeler PA, Thorgaard GH: Transcriptome profiles of livers and kidneys from three rainbow trout (Oncorhynchus mykiss) clonal lines distinguish stocks from three allopatric populations. Com Biochem Physiol 2006, 1:396-403.

62. Roberge C, Einum S, Guderley H: Bernatchez Rapid parallel evolutionary changes of gene transcription profiles in farmed Atlantic salmon. Mol Ecol 2006, 15:9-20.

63. Doñate, Balasch JC, Callol A, Bobe J, Tort L, Mackenzie S: The effects of immunostimulation through dietary manipulation in the rainbow trout; evaluation of mucosal immunity. Mar Biotechnol 2010, 12(1):88-99.

64. Byon JY, Ohira T, Hirono I, Aoki T: Use of a CDNA microarray to study immunity against viral hemorrhagic septicemia (VHS) in Japanese flounder (Paralichthys olivaceus) following DNA vaccination. Fish Shellfish Immunol 2005, 18:135-147. 
65. Martin S, Blaney SC, Houlihan DF, Secombes CJ: Transcriptome response following administration of a live bacterial vaccine in Atlantic salmon (Salmo salar). Mol Immunol 2006, 43:1900-1911.

66. Jorgensen SM, Afanasyev S, Krasnov A: Gene expression analyses in Atlantic salmon challenged with infectious salmon anemia virus reveal differences between individuals with early, intermediate and late mortality. BMC Genomics 2008, 9:179-186.

67. Aluru N, Vijayan MM: Stress transcriptomics in fish: A role for genomic cortisol signaling. Gen Com Endoc 2009, 164:142-150.

68. Roher N, Callol A, Planas J, Goetz F, Mackenzie S: Endotoxin recognition in fish results in inflammatory cytokine secretion not gene expresión. Innate Immun 2010, 10:245-267.

69. Hinz B, Brune K: Cyclooxygenase-2-10 years later. J Pharmacol Exp Ther 2002, 300(2):367-375.

70. Chen BC, Liao CC, Hsu MJ, Liao YT, Lin CC, Sheu JR, Lin CH: Peptidoglycaninduced IL-6 production in RAW 264.7 macrophages is mediated by cyclooxygenase-2, PGE2/PGE4 receptors, protein kinase A, I kappa B kinase, and NF-kappa B. J. Immunol 2006, 177:681-693.

71. Chen BC, Kang JC, Lu YT, Hsu MJ, Liao CC, Chiu WT, Yeh FL, Lin CH: Rac1 regulates peptidoglycan-induced nuclear factor-kappaB activation and cyclooxygenase-2 expression in RAW 264.7 macrophages by activat- ing the phosphatidylinositol 3-kinase/Akt pathway. Mol. Immunol 2009, 46:1179-1188

72. Urade $Y$, Hayaishi O: Prostaglandin D synthase: Structure and function. Vitam Horm 2000, 58:89-120.

73. Kanaoka Y, Urade Y: Hematopoietic prostaglandin D synthase. Prostaglandins Leukot Essent Fat Acids 2003, 69(3):163-167.

74. Stenbak C, Ryu J, Leulier F, Pili-Floury S, Parquet C, Herve M, Chaput C, Boneca I, Lee W, Lemaitre B, Mengin-Lecreulx D: Peptidoglycan molecular requirements allowing detection by the Drosophila immune deficiency pathway. J. Immunol 2004, 173:7339-7348.

75. Royet J, Dziarski R: Peptidoglycan recognition proteins: pleiotropic sensors and effectors of antimicrobial defences. Nature Rev Microbiol 2007, 5(4):267-277.

76. McDonald C, Inohara N, Nuñez G: Peptidoglycan Signaling in Innate Immunity and Inflammatory Disease. J Biol Chem 2005, 280(21):20177-20180.

77. Baoprasertkul P, Peatman E, Abernathy J, Liu Z: Structural characterisation and expression analysis of Toll-like receptor 2 gene from catfish. Fish Shellfish Immun 2007, 22(4):418-426.

78. Hoebe K, Du X, Georgel P, Janssen E, Tabeta K, Kim S, Goode J, Lin P, Mann N, Mudd S, Crozat K, Sovath S, Han J, Beutler B: Identification of Lps2 as a key transducer of MyD88-independent TIR signalling. Nature 2003, 424:743-748

79. Jiang Z, Georgel P, Du X, Shamel L, Sovath L, Mudd S, Huber M, Kalis C Keck S, Galanos C, Freudenberg M, Beutler B: CD14 is required for MyD88independent LPS signaling. Nature Immunol 2005, 6(6):565-573.

80. Akira S: Mammalian Toll-like receptors. Curr opin 2003, 15:5-11.

81. Locksley RM, Killeen N, Lenardo MJ: The TNF and TNF receptor superfamilies: integrating mammalian biology. Cell 2001, 104(4):487-501.

82. Cha GH, Cho KS, Lee JH, Kim M, Kim E, Park J, Lee SB, Chung J: Discrete Functions of TRAF1 and TRAF2 in Drosophila melanogaster Mediated by c-Jun N-Terminal Kinase and NF-B-Dependent Signaling Pathways. Mol Cell Biol 2003, 23(22):7982-7991.

doi:10.1186/1471-2164-12-34

Cite this article as: Boltaña et al:: Divergent responses to peptidoglycans derived from different $E$. coli serotypes influence inflammatory outcome in trout, Oncorhynchus mykiss, macrophages. BMC Genomics 2011 12:34.

\section{Submit your next manuscript to BioMed Central and take full advantage of:}

- Convenient online submission

- Thorough peer review

- No space constraints or color figure charges

- Immediate publication on acceptance

- Inclusion in PubMed, CAS, Scopus and Google Scholar

- Research which is freely available for redistribution 